\title{
Brudstykker af det litterære på nettet
}

\author{
Af Mette Strømfeldt
}

\section{Forhistorier}

I disse tider er der en del hype omkring nye teknologier og dingenoter, der gør litteratur tilgængelig på hidtil uset måde: man kan hente glasbøger ned fra nettet, fægte rundt med E-bogskonsoller og få print-on-demand. Det lyder forjættende, og er det. Litteraturen rejser igennem nye kanaler og måske endog til destinationer, den ikke har set før. Er man på forhånd som læser blot en smule velbevandret i litteraturens verden, er det først og fremmest iøjnefaldende hvor meget velkendt litteratur, der får sig en tur i maskinen. De gamle klassikere er ikke sådan til at komme uden om, og så koster de åbenbart heller ikke noget. Helt gratis kan man downloade eksempelvis Jules Verne, Henry James, Bram Stoker, Robert Louis Stevenson og Lewis Carroll. Med værker som Stevensons The Strange Case of Dr Jekyll and $\mathrm{Mr}$ Hyde (1886) indlemmet i glasbibliotket er jeg så parat til at afprøve den nye bogs muligheder. Jeg kan sætte min laptop på højkant og holde den som en bog for på den måde at mindske springet fra bog til skærm, men lige meget hvordan jeg end vender og drejer det, undrer det mig nu først og fremmest, at det nydelige layout ikke indbefatter en bladrelyd, når jeg går fra side til side. I det hele taget går det hurtigt op for én, at software som Glassbook Reader og Microsoft Reader mest af alt fungerer som en slags glasbure for litteraturen, der sætter grænser for hvor meget E-teksterne kan sættes $i$ korrespondance med computerens andre dokumenter. Der kan ikke printes og det er begrænset hvor lange citater, der kan hentes over på clipboard. Det skyldes naturligvis, at blandt andet burets udformning skal sikre, at E-bøgerne ikke bliver genstand for videre uautoriseret distribution. Ellers ville det være så som så med fremtiden for dette som forretning.

Bliver man træt i øjnene af at hoppe rundt i Ebøger, man alligevel allerede har læst, kan det selvfølgelig også være, at det slår én, hvor pudsigt det er, at netop ovennæunte forfattere bliver gjort tilgængelige i denne form for ramme. På hver deres måde hører de 'utvivlsomt til nogle af litteraturens mest fremtrædende teknologer. Tænk blot på fortæller-i-fortæller rammen i The Turn of the Screw (1898) af Henry James og Stevensons og Stokers brug af forskellige dokumenttyper til at skabe suspense. I Dracula (1897) er det således den stenograferende Mina, der har renskrevet og ordnet breve, dagbøger, avisudklip og indtalinger på fonografiske cylindre, så professor Van Helsing kan få et overblik over sagens rette sammenhæng. Faktisk er det først, da Mina ikke længere fungerer som informations- og kommunikationscenter, da hun bliver "kept in the dark," at også hun fanges ind i Draculas mørke (1). Dette aspekt når sjældent til filmlærredet, som de fleste nok kender 
Dracula fra, ligesom sammenstykningen af de forskellige beretninger i Dr Jekyll and Mr Hyde ikke lader sig direkte overføre til film.

Ved en (gen)læsning af disse klassikere er det nu slående hvor afgørende denne virtuose tekstbehandling er for romanernes uhygge. På lignende vis er det nok heller ikke tilfældigt, at Jules Verne valgte at levere sin science fiction om fremtidens naturvidenskabelige opdagelser og teknologiske landvindinger via en fortællerstemme, der skaber en øjenvidneberetnings autenticitet, som i En verdensomsejling under havet (1869). På Vernes tid havde pressen skam fået øjnene op for de mange og gode historier, der var i videnskabernes sejrstogt, og aviserne var fulde af beretninger om videnskabelige og tekniske bedrifter. Det nåede nok ikke helt de samme højder som for eksempel vore dages IT-glade pressedækning, men Verne kunne udmærket tillade sig at spille på den aura af noget autentisk, en beretning eller dagbog skrevet af en opdagelsesrejsende i videnskabens eller den virkelige verden var omgærdet med, da han fra 1864 begyndte at skrive til tidens magasiner for oplysning og underholdning.

I den anden ende af det litterære og æstetiske barometer befinder den omhyggelige wordprocessor Lewis Carroll sig. Med sine gådefulde ordspil og tegnlege arbejder han på det litteræres mindste byggesten. I The Hunting of the Snark (1876) har han nu også plads til at give den omhyggelige kortlægning af verden et par kommentarer med på vejen. Kaptajnen i The Hunting navigerer nemlig efter et blankt kort:

And the crew were much pleased when they found it to be

A map they could all understand.
"What's the good of Mercator's North Poles and Equators,
Tropics, Zones, and Meridian Lines?"
So the Bellman would cry: and the crew would reply
"They are merely conventional signs! (2)

At disse forfattere alle fortjener at komme I glas og ramme, er der ingen tvivl om, men måske det var værd at overveje deciderede netversioneringer af deres værker, der brugte hypertekst og hypermedie mulighederne anderledes radikalt end det sker i glasbogens noble regi. Hvorom alting er, kunne det utvivlsomt have været interessant at se hvorledes netop disse forfattere ville have udnyttet $\mathrm{og}$ reageret på et fænomen som nettet og forestillingerne om cyberspace, ikke mindst fordi teknologi og videnskab spiller en markant rolle i så godt som alle forfatterskaberne, tematisk såvel som æstetisk.

I det følgende vil jeg således diskutere nogle af de anderledes litterære tendenser, der er at finde på nettet, tendenser der på mange måder fortsætter og udbygger de angrebsvinkler, de hidtil omtalte litterære teknologer udviklede og benyttede sig af. Jeg har bestræbt mig på at lave nogle velvalgte punktnedslag, der kan danne grundlag for en foreløbig kortlægning, selvfølgelig med Carroll citatet in mente. De overskrifter jeg behandler de aktuelle tendenser under nedenfor er: netbegivenheder, der kan læses som radikaliseringer af Stokers og Stevensons projekter, e-mailromaner, der kunne have været Vernes foretrukne føljetonmedie i dag og kunstskrift, hvor vi måske ville have fundet en Lewis Carroll. Først vil jeg dog opholde mig ved to eksempler på begyndelser til det litterære på nettet, der nødigt skulle gå i glemmebogen og desuden giver et meget godt indtryk af hvilke yderligheder, man reelt bevæger sig indenfor, når man forsøger at få et overblik over dette område.

\section{Begyndelser}

"There is continuity, after all, across the ages riven by shifting technologies."

Robert Coover, "The End of Books" (3)

At indlede dette afsnit med et citat fra Robert Coover er på mange måder på sin plads. Ikke alene har Coover siden 1980 været primus motor i det creative writings program på Brown University, der er kendt for sit pionerarbejde med hypermedierede elektroniske fiktioner, sammen med eksempelvis John Barth regnes han også blandt de forfattere, der i dag omtales som klassiske amerikanske postmodernister. (4) Coover legemliggør således det oplagte $\mathrm{i}$ at tage springet fra papiret til det digitale for den postmodernistiske forfatter, 
ligesom de konferencer han arrangerer på Brown University under overskriften "Unspeakable Practices" med tiden har udvidet målgruppen postmodernister til også at inkludere post-postmodernister, cyberpunk forfattere og hypertekstskribenter. Snart tilføjes vel også en betegnelse for forfattere, der arbejder specifikt med netlitteratur.

Brown University er også "home," så at sige, for en i denne sammenhæng vigtig teori. Det er nemlig også her George Landow stod fadder til hypertekstteorien (5). Coover og Landow mødes i deres bestræbelser på at påpege, hvorledes det postmodernistiske og det poststrukturalistiske tekstarbejde fortsættes i hyperspace, steder hvor hypertekst anvendes. Indenfor hypertekstteorien lyder det af og til som om poststrukturalismen øjeblikkeligt indfinder sig i dette hyperspace uanset hvad. Den slags kortslutninger er mere end problematiske, og tiden har vel også vist, at hypertekst muligheder ofte ikke munder ud $\mathrm{i}$ andet end en "user friendliness," der på ingen måde tilnærmelsesvis er beslægtet med teoriforbillederne Roland Barthes' og Jacques Derridas skriverier og tanker. I modsætning hertil virker Coovers betragtninger mere besindige, måske fordi de er forankret i det konkrete arbejde med at forløse hypertekst potentialerne. I førnævnte artikel, "The End of Books," er Coover således påpasselig med først og fremmest at anføre, at hans egne og andres bestræbelser blot følger i for eksempel Cervantes', Lawrence Sternes og James Joyces spor. Coover understreger kontinuiteten, og den dynamik og efterforskning, der driver værket, hæudes på ingen måde at være ny. Hyperfiktion er simpelthen blot det oplagte sted at fortsætte det litterære laboratoriearbejde af følgende årsager:

No fixed center, for starters--and no edges either, no ends or boundaries. The traditional narrative time line vanishes into a geographical landscape or exitless maze, with beginnings, middles and ends being no longer part of the immediate display. Instead: branching options, menus, link markers and mapped networks. There are no hierarchies in these topless (and bottomless) networks, as paragraphs, chapters and other conventional text divisions are replaced by evenly empowered and equally ephemeral window-sized blocks of text and graphi- cs-and soon to be supplemented with sound, animation and film.

Man ser, hvorledes nærmest hele det postmodernistiske katalog oprulles, og hvorledes tilføjelsen af lyd, animation og film også varsler om nedbrydelsen af grænserne til andre kunstarter, en mulighed der er blevet endnu mere tydelig i dag, hvor ordet hypermedie efterhånden har afløst hypertekst. På trods af disse tilløb til at være medieoverskridende bevarer Coover dog hele tiden sit udgangspunkt i litteraturen og taler om læsere og skribenter:

With hypertext we focus, both as writers and readers, on structure as much as on prose, for we are made aware suddenly of the shapes of narratives that are often hidden in print stories.

Således skal "The End of Books" ikke ses som et postulat om at bogen vil forsvinde, men derimod som en forklaring på, hvorfor visse litterære virksomheder og tendenser bedst forfølges $\mathrm{i}$ hyperspace. Endelig er det også værd at notere sig, at Coover opstiller følgende kriterium for et hypertekstuelt værk:

Print documents may be read in hyperspace, but hypertext does not translate into print.

Der var derfor også floppy disks og senere CDROM'er, der kom ud af disse bestræbelser, eller online fiktionslaboratorier som Hotel, hvor skribenter kunne checke ind og lade deres skriverier blive forstyrret, udbygget eller blandet med andres (6). Mit andet eksempel på en begyndelse kunne umiddelbart se ud til at have noget tilfælles med fiktionsrummet Hotel. The World's First Collaborative Sentence er også et "multi-user" miljø, men hvor Hotel er forbeholdt gæster, som er indforstået med visse spilleregler og enige om bestemte præmisser for hvordan der skal arbejdes med og på litterære konventioner, så er The Sentence åben for alle, blot man overholder reglen om ikke at afbryde sætningen med et punktum. Man behøver altså ikke gå på forfatterskole for at være med her. Sætningen blev sat i gang i 1994 af Douglas Davis og har siden 1995 været en del af Whitney Museets samling af internetkunst (7). David Ross var direktør for Whitney museet $1991-1998$ 
og blev fra 1998 direktør for SFMoMA. Dette museum for moderne kunst i San Francisco har på nuværende tidspunkt et langt mere veludviklet hyperspace for netkunst end Whitney, hvilket jeg vender tilbage til senere, og det er absolut ingen tilfældighed, at Ross er at finde på museer, der er parate til at indlemme de seneste medier som nogle af de første, da Ross i 1971 blev en af kunstverdenens første kuratorer af videokunst. Begynder man på The Sentence, er det forste, der kommer en i møde da også et uskarpt billede fra videokunstens tidlige ăr, som den ledsagende tekst kommenterer således:

The temporary author-artist of these lines and this work is Douglas Davis. In face he (cf. me) is facing you at this moment, from a moment in 1973 when he, that is, me, tried to focus the lens of his video camera directly on you, the viewer on the other side of the then-imperial TV screen. Well, we have broken that screen down many times then-_"we" being the early video artists determined to destruct the big lie that TV was a mass one-way medium, you, impatient viewer who lusted for something better (and finally got it, in lots of ways), and the inexorable roll of technological innovation, moving us finally into the digital era and THIS MEDIUM, the InterNet/Web, where you take over from me... (8)

Douglas Davis skilter altså ligefrem med forbindelsen fra videokunst til netkunst. Ligesom David Ross ønsker Davis at holde fast i de "samfundsændrende" ideer, der var et vigtigt aspekt af den tidlige videokunst. (9) Hvis megen videokunst på nuværende tidspunkt har fundet sig en sikker havn på gallerier og museer, er Davis og Ross interesseret $i$ at kultivere det aspekt af videokunsten, der var en kommentar til massekommunikationssamfundet og fors $\emptyset$ gte sig med to- eller flervejskommunikation, et aspekt der ikke er tjent med rammerne i det traditionelle museum. I sin tid fors $\varnothing$ gte Ross da også at realisere planer om en tv-kabelkanal i tilknytning til et af de museer, han arbejdede for, og kunstnere fors $\emptyset$ gte $\mathrm{i}$ det hele taget at sikre sig kabelplads, så deres arbejde kunne ligge som en kommentar og et alternativ i den kommercielle broadcasting kontekst, de ønskede at kommentere. Men forhåbningerne til kabel-tv er for længst glemt (10). I stedet har den teknologiske udvikling så bragt os nettet, og både David Ross og Douglas Davis ser det som den ultimative nye legeplads, der skal indfri de gamle forhåbninger og løftet om hul-i-gennem på radikal vis.

The Sentence skal læses som et virtuel monument til disse forhåbninger. De enorme tekstmængder dokumentet efterhănden indeholder kan næppe kaldes litteratur, men som begyndelse markerer sætningen en ydergrænse præcis på samme måde som Coovers og andre hypertekstskribenters litterære spilfægterier. Dertil kommer, at værket kan læses som et missing link, der tydeligg $\varnothing r$ kontinuiteten til hypermediet fra de tidlige, i dette tilfælde amerikanske, fors $\emptyset \mathrm{g}$ på at nedbryde skellet mellem genrer og kunstarter. Denne periode starter i 60'erne og kan med fordel læses som begyndelsen på den amerikanske postmodernisme, hvilket eksempelvis Andreas Huyssen har argumenteret for (11). Mit ærinde her er ikke en postmodernisme diskussion, men som Coover tror jeg, det er værd at fremhæve kontinuiteten og ligefrem nødvendigt at have blik for den, hvis man skal skrive sig ind på hypermediet. Er man således interesseret $\mathrm{i}$ hvad der sker med det litterære på nettet, kan det være produktivt at skele til nogle af de betragtninger, der meldte sig, da billedkunstnere begyndte at føle maleriets ramme for snærende og sidst i 50'erne kastede sig ud i happenings og dermed tog hul på den forvirring og blanding af kunstarterne, der er blevet fortsat $\mathrm{i}$ former som performance, site-specific kunst, videokunst, installationskunst og nu hypermediekunst. I 1962 skriver Susan Sontag i en artikel om happenings, at kunstnere som Robert Rauchenberg og Allan Kaprow begyndte at arbejde med assemblager:

...a hybrid of painting, collage, and sculpture, using a sardonic variety of materials, mainly in the state of debris, including license plates, newspaper clippings, pieces of glass, machine parts, and the artist's socks. From the assemblage to the whole room or "environment" is only one further step. The final step, the Happening, simply puts people into the environment and sets it in motion. (12).

Følgelig er happenings også blevet kaldt kunstmalerens teater og via Antonin Artaud og dennes 
teorier om grusomhedens teater skyder Sontag sig ind på, hvad der er på spil i happenings:

What goes on in Happenings merely follows Artaud's prescription for a spectacle which will eliminate the stage, that is, the distance between spectators and performers, and "will physically envelop the spectator." (p. 276)

Hvor Sontag så potentialer i denne teatralisering af kunsten og forholdet mellem "værket" og tilskueren/publikum, så Michael Fried i 1967 selvfølgelig tendensen som modernistisk kunsts værste fjende:

For theatre has an audience-it exists for one - in a way other arts do not; in fact, this more than anything else is what modernist sensibility finds intolerable in theatre generally (13).

Fried mener derfor, at kunsten degenererer, når den nærmer sig teatrets betingelser og fortsætter:

The concept of quality and value--and to the extent that these are central to art, the concept of art itself-are meaningful, or wholly meaningful, only within the individual arts. What lies between the arts is theatre. (p. 831)

Lige meget om man deler Sontags optimisme eller Frieds pessimisme, kan deres betragtninger om teatralisering være produktive, ikke mindst fordi happenings ikke skulle blive det sidste skridt, som Sontag anforte, men blot endnu et $\mathrm{i}$ en stribe, der har mudret skellene mellem kunstarterne mere og mere. Leder man med andre ord efter brudstykker af det litterære på nettet, i hyperspace, leder man måske snarere efter iscenesættelser af det litterære, der involverer og inddrager læseren på en måde, det ikke var muligt for bogen og heller ikke bliver det for E-bogen. Hvorvidt der så overhovedet længere er tale om litteratur, er et godt spørgsmål, men kan måske vise sig at være mindre vigtigt, når man jagter virtuelle efterfølgere til Stevenson, Verne og Carroll.

\section{Netbegivenheder}

I 1997 modtager Michael Krantz, journalist på TIME, en E-mail fra en Denny Reikert, der for- hører sig vedrørende referencenumre på nogle konti. Reikert arbejder for the Dysson Foundation, og Krantz aner ikke, hvem han er eller hvad han taler om. Han mailer tilbage og meddeler Denny Reikert dette, der straks svarer og beder ham slette den vildfarne mail. Denne misforståelse bliver indledningen til en livlig korrespondance mellem Krantz og medlemmer af Dysson organisationen, da Denny Reikert dør, og Krantz modtager E-post, der fors $\varnothing$ ger henholdsvis at dække over eller opklare omstændighederne omkring Dennys død. I de næste to uger modtager og svarer Krantz således på mail fra andre Dysson involverede, og undervejs forsøges han også rekrutteret til organisationen og bliver henvist til deres hjemmeside:

...which is written in creepy corporate prose and looks just as one would expect a "global telecommuting consortium" to look, complete with geeky employee photos and a client list that includes Time Warner, the parent company of this magazine (14).

Omsider afsløres det dog, at Denny affæren er det rene humbug. Det hele har været et eksperiment, som teamet LaFong selv kalder det (15). LaFong består af (manuskript)forfatter Michael Kaplan og videokunstner/instruktør John Sanborn og specialiserer sig i interaktive fiktioner. Den første vildfarne mail blev oprindeligt sendt til 40 udvalgte ofre. Denne målgruppe bestod af ledere i ITbranchen, personlige venner, et gammelt Monty Pyton medlem, Eric Idle, og journalister. Reaktionerne var mange og nogle kontaktede endog politiet. Efter afsløringen var især Eric Idle rasende og karakteriserede hele affæren som en form for kommunikativt hærværk.

I den sidste mail i føljetonen stod der:

You were helpful... You were amused. You were spooked. You were hooked. You were pitched... (16).

At blive "pitched" er nogenlunde det same som at blive "conned," at hoppe på den, at blive snydt. En "con artist" eller "confidence trickster" er oprindeligt en amerikansk storbytype, der for alvor trådte i karakter i midten af 1800 -tallet, men vi kender også slagsen fra H. C. Andersens "Kejse- 
rens nye klæder." Det interessante ved en "con artist" i denne sammenhæng, er hans/hendes færdigheder som kommunikationsarbejder. Hvad enten det er mundtligt eller skriftligt, lykkes svindleriet kun hvis der kommunikeres virtuost nok til at bedrageriet ikke opdages. På den måde kan man roligt sige, at LaFong med Dysson eksperimentet var virtuose nok til at deres "con act" lykkedes. Folk hoppede på den, købte historien, hvilket forklarer eksempelvis Eric Idles raseri. I stedet for at blive rasende kunne man også vælge at se Dysson eksperimentet som en vellykket "hoax," et vellykket nummer eller røverhistorie:

Hoax was a popular nineteenth-century form of entertainment that tested the intelligence of the audience; it was less a form of deception than a form of interrogation and invitation to find the flaw in an apparent natural truth (17).

En af de berømteste hoaxere eller humbugmagere er P.T. Barnum. Fra han i 1840 'erne åbner sit American Museum i New York, iscenesætter han det ene humbugnummer efter det andet til publikums store begejstring. The American Museum var med vore øjne set en mærkelig blandet landhandel, og det kan være svært at forstå, at stedet overhovedet fortjente betegnelsen museum. Hos Barnum udstilledes strikkemaskiner, dværge, jonglører, forsteninger, panoramaer, daguerreotypier, dyr (udstoppede og levende), havfruer, kunst, møntsamlinger og indianere på lige fod, og stedet bød også på musikalsk underholdning, opbyggeligt teater og populærvidenskabelige forelæsninger 18). Dette raritetskabinet kan på den ene side affærdiges som det rene gøgl, men på den anden side kan det også læses som en slags urscene, dels for stedet hvor folkeoplysningen tog nogle vigtige første skridt, dels for hvor en ny moderne sensibilitet eller opmærksomhed blev kultiveret (19). Det er det sidste, jeg vil hæfte mig ved her. Neil Harris har i sin bog om Barnum beskrevet, hvorledes humbug er en operationel æstetik:

The objects inside the museum, and Barnum's activities outside, focused attention on their own structures and operations, were empirically testable, and enabled-or at least invited-audiences and participants to learn how they worked. They appealed because they exposed their process of action. Adding an adjective to the label, one might term this an "operational aesthetic," an approach to experience that equated beauty with information and technique, accepting guile because it was more complicated than candor $(20)$.

Når Barnum således sætter det store mediecirkus i scene for at få udstillingen af eksempelvis the Fejee Mermaid til at blive et tilløbsstykke, inviterer han publikum til at bedømme og vurdere selve genstanden, men også de til lejligheden frembragte og i nogle tilfælde fabrikerede ekspertudtalelser og dokumenter. At Barnum ved denne såvel som andre lejligheder formår at score dobbelt, det vil sige, først får publikum ind for at se om havfruen er ægte, senere for at unders $\emptyset$ ge den som en "genuine fake," en ægte forfalskning, siger noget om den dynamik, der er karakteristisk for humbug: humbug er vellykket, når vi hopper på numret (eller næsten gør det eller en stor del af publikum gør det) og afsløringen efterfølgende får os til at overveje, hvordan og hvorfor det kunne lade sig gøre.

Dysson eksperimentet opererer med den samme dynamik, men hvor Barnum "broadcaster," som Neil Harris udtrykker det, er LaFong med nettet og E-mail som medie i stand til at involvere publikum/læseren meget mere direkte (21). Dysson eksperimentet var en netbegivenhed, der betjente sig af humbug som operationel æstetik. Dermed rejser begivenheden ikke alene nogle vigtige spørgsmål til vores forestillinger om, hvordan vi navigerer i hyperspace og skelner sandt fra falsk. Begivenheden fortæller også en historie, hvor informationer og oplysninger kan være livsfarlige og koste livet (her Dennys) i kampen om millionerne på den globale telekommunikative arena. At LaFong slipper af sted med denne røverhistorie, skyldes ikke mindst iscenesættelsen og teatraliseringen af cirkulationen af dokumenter og at disse dokumenter er udformet på en måde og skrevet skærmklart nok til at læseren falder for numret. Som Sontag fremhævede, bliver de traditionelle rammer brudt, og læseren vikles ind i historien. Ja, faktisk kan man gå så langt som til at sige, at denne hoppen på/ind i historien er en nødvendighed for at den lever (22). 
På alle leder og kanter er Dysson begivenheden dermed en kommentar til informationssamfundets nyeste kommunikationsformer og spillet om disse. Ydermere er det også et hypermedieprojekt, der lever op til Coovers krav om, at det ikke lader sig direkte oversætte til trykte dokumenter. Det er da også karakteristisk, at LaFong arbejder på at lave en tv-serie om Dysson eksperimentet, det vil sige om netbegivenheden og ikke en serie om Denny. Som anden humbug problematiserer Dyssons dynamik egentlige adaptioner fra det ene medie til det andet. I stedet for adaptioner har vi at gøre med en slags generator, der bliver ved med at lægge til historien og at kaste nye aspekter af historien af sig, idet den bevæger sig fra det ene medie til det andet (23). Begivenheden er og bliver en del af historien. Jeg var tidligere inde på Minas rolle i Dracula. Hvor Stoker lod os læse over skulderen på Mina, kræver en netbegivenhed som Dysson, at læseren træder i Minas sted, spiller hendes rolle. Læseren bliver den, der holder styr på de forskellige dokumenter og står for en eventuel verificering. Således får læseren også at føle på egen krop de mulige konsekvenser af at blive "kept in the dark," for som Dysson eksperimentet ville vise:

...even if the exchanges are simple and fictional, the E-mail medium is intimate and the emotions attached to it are real (24).

\section{E-mailromaner}

Det er i dag også muligt at abonnere på E-mailromaner. I det øjeblik man giver tilsagn om at ville modtage en E-mailroman, er muligheden for at skabe en netbegivenhed naturligvis forpasset. Man kender E-postens afsender, og selvom det er opsigtsvækkende, bliver man ikke skræmt over at modtage mail fra Patrick Bateman, når man selv har bestilt det. Med E-mailromaner har vi at gøre med en levendegørelse og iscenesættelse af den gamle brevromanform, der ikke involverer humbug, men ikke desto mindre udnytter det særegne ved nettet.

De eksempler jeg ser nærmere på her, er alle taget fra Email Shows( (25). Email Shows( havde deres første premierer i februar 2000 og blev for alvor kendt med Am.Psycho2000. Denne Emailroman består af 50 mails, der indløber over en periode på halvanden måned. Vi får et indblik i Patrick Batemans korrespondance år 2000, og der er således tale om en slags fortsættelse til American Psycho af Bret Easton Ellis fra 1991. Fortsættelsen er ikke skrevet af Bret Easton Ellis selv og skal da også ses som et led i promoveringen af filmatiseringen af bogen. Koblingen mellem filmlancering og Email Shows( er ikke tilfældig og er også blevet udnyttet i forbindelse med premiererne på Erin Brockovich og DVD-udgaven af Se7en. Email Shows( er en forretning: hvis man kan anskue eksempelvis amerikanske tv-serier som emballage for reklamer, består emballagen i dette tilfælde af mails. Når E-posten endvidere er i korrespondance med det lancerede, for eksempel en film, kan det enten komme til at virke som en unaturlig påklistring, men kan også resultere i et spændende supplement. Hvorom alting er, mener jeg, det kan være værd at holde $\varnothing j \mathrm{je}$ med dette fænomen, fordi det giver et indblik i nogle af de potentialer E-mailromaner har.

Udover de omtalte værker tilbyder Email Shows( rejsebreve og breve der handler om livsstil og mad og sex. Udnyttelsen af disse genrer er nærmest oplagt: personlige betragtninger fra skribenten ender i modtagerens private mailbox og illuderer en form for personlig og intim kommunikation, bøger om samme emner ikke er i stand til. Samtidig kan links vedhæftes, så læseren hurtigt kan komme i kontakt med de steder, hvor der skal forbruges efter den foreskrevne livsstil. I modsætning hertil lever fiktionsværkerne højt på en slags voyeurisme, hvor læseren bliver vidne til de fiktive personers privatkorrespondance. The Boy Next Door af Patricia Cabot er en romance og original skrevet til Email Shows(. Med sine snart 500 mails, mindst to om dagen i over et halvt år, er den nærmest et eksperiment $\mathrm{i}$ udholdenhed. Disses personers problemer med kærlighedslivet og forvekslede identiteter er ærlig talt ikke videre spændende, men tonen og illusionen af sladder, der blander sig i den daglige arbejdsmail, er meget godt ramt. I forhold hertil er Am.Psycho2000 meget mere interessant, fordi den fabulerer over Batemans liv i dag, og hvad der videre hændte med personerne i hans omgangskreds. Man skal have læst romanen for at kunne følge med og der abonneres således også på en vis indforståethed. 
Se7en består af 31 mails og varer lidt over en måned. I denne seance bliver læseren hyret af William Somerset til at give en profil af John Doe til hjælp i opklaringen af sagen og får derigennem adgang til sagens relevante filer. Imidlertid viser John Doe sig også at være en habil hacker, og han erhverver sig læserens/profilerens adresse og begynder at sende de oplysninger og kommentarer, som han finder relevant. Har man set filmen, er det eneste nye denne inddragelse af en profiler, der spilles af læseren, men det fungerer til gengæld også utroligt godt, og som det mest vellykkede produkt fra Email Shows( udstiller Se7en nogle af de muligheder, deriblandt en mere gennemtænkt brug af links, der åbner sig med E-mailromaner. Man kunne på denne baggrund ønske, at seriøse forfattere ville prøve kræfter med E-mailromanen. Eksempelvis måtte efterfølgere til Jules Verne (en Michael Crichton type?) kunne få et anderledes kreativt spillerum end i den trykte bog og det uden at blive beskyldt for kommunikativt hærværk som ved netbegivenheder.

\section{Kunstskrift}

\section{Young-hae Chang Heavy Industries Presents}

Young-hae Chang er ligesom de andre netkunstnere, jeg kommer ind på i dette afsnit, omtalt på SFMOMAs site for netkunst e-space (26), som er kommet til, efter at David Ross er blevet direktør for museet. I udtalelsen fra juryen, der udpegede vinderen af SFMOMAs Webby Prize d. 12. maj, 2000 , får hun "honerable mention" for sine konceptuelle parabler. Chang er blot en af et overvældende antal netkunstnere, der er yderst ordglade og hovedsageligt arbejder i tekst. Der er ikke tale om åbne værker som The Sentence. Værkerne er lukkede i den forstand, at der ikke kan skrives til, og det der er på spil er en afsøgning af teksten på skærmen og skriftens funktion i hyperspace. "Artist's Statement No. 45,730.944: The Perfect Artistic Website" i Young-hae Chang Heavy Industries Presents er efter min mening det mest præcise af hendes værker (27). Ligesom de andre værker i Heavy Industries Presents indledes teksten med en nedtælling: "10 - 9-8...," som vi kender det fra film. Ledsaget af musik, en gammel ridset liveoptagelse af et jazznummer (28), slynges ordene så $\mathrm{i}$ hovedet på os, for Chang taler med store bogstaver. Der bliver noget hypnotisk over bog- staverne og ordene, når de forst $\varnothing$ rres op og i sort på hvidt pulserer frem på skærmen, og et enkelt "I" der fylder hele skærmen går hen og får skulpturelle kvaliteter. Teksten kan derfor heller ikke læses på sædvanlig vis, altså hvor øjnene følger linien fra venstre mod højre. I stedet må man nærmest overgive sig til teksten og lade den pulsere en i møde, for selvom skærmen indeholder flere ord, er der simpelthen ikke tid til at flytte blikket. Dette resulterer i en helt unik læseoplevelse. Da teksten handler om det kunstneriske website, får Chang lejlighed til at filosofere over diverse aspekter ved nettet. Hun skitserer indledningsvis en situation, hvor hun befinder sig i cyberspace og "WAITING FOR REPLY," disse ord får lov til at stå påfaldende længe i forhold til andre. "STILL WAITING," får hun, som hun skriver, "TIME TO REFLECT."

Herefter følger tanker om nettets betydning, hvor den personlige ekshibitionistiske brug sættes i kontrast til en mere politisk og lokalt geografisk betinget. Chang er fra Sydkorea, og forholdet til Nordkorea på nettet bliver skildret som en hvemovervåger-hvem dynamik. Det lokalpolitiske får dog en helt særegen karakter som så meget andet i cyberspace, hvor selv de mest essentielle spørgsmål ofte besvares med et: "WHAT IS YOUR CREDIT CARD NUMBER?" Hele seancen slutter med, at Chang tager sin ene sok af, på en og samme tid parodierende cybersex, men vel også med hilsener til andre kunstneres sokker (29), og dette "COVERSATIONAL PIECE" putter hun så i munden og udtrykker et "MMM" som skulpturelt ligner WWW på hovedet.

Herefter starter teksten forfra, og denne loopeller tekstsløjfevirkning spejles også undervejs i kompositionen, som om Changs forsøg på at kommunikere ud i verdenen hele tiden falder tilbage $\mathrm{i}$ sig selv i selve teksten. Changs lystfyldte og selvsmagende måde at erklære sig på i cyberspace er træfsikker i sin udlevering af både netkommunikationens præmisser og den kendsgerning, at ord langt fra er uskyldige formidlere og konstrukt $\varnothing$ rer af identitet, af et "I." Changs arbejde med ordene som minimaler og nettets mindste byggesten er derfor et eller andet sted i korrespondance med Lewis Carrolls tegn- og ordlege. På samme måde mener jeg, at Carroll ville have fundet det følgende værk interessant. Det henter sine stikord fra 
eksperimenter i MIT's Visual Language Laboratory. The Lair of the Marrow Monkey af Erik Loyer er en del af SFMOMAs permanente samling af netkunst (30). Som han selv udtrykker det, er værket en interaktiv efterforskning af det forførende ved digital abstraktion. Hovedpersonen i The Lair, Orion17, er en minimalistisk komponist, der efter at have haft en euforisk vision og intens oplevelse af at være et med "the world of abstraction," slutter sig til en forskergruppe, der eksperimenterer med at (gen)skabe en lignende form for eufori. Historien fortælles i tekst og ledsages af musik, til tider recitering af teksten. Det er en god historie og pointen er naturligvis, at den eufori Orion 17 jagter, kan lignes med den eufori, læseren kan komme til at opleve, når der interageres og man bliver et med den digitale abstraktion af teksten, som en læsning af værket kræver. Loyer arbejder med og gennemprøver en hel katalog af scroll teknikker i The Lair. Indholdsfortegnelsen er en slags spilledåse, og de 9 kapitler er vidt forskellige eksperimenter, som læseren aktiverer ved at kæle for teksten med cursoren. Til tider skal tekstfragmenterne samles som et slags puslespil, andre gange skal der læses igennem de palimpsest virkninger, der fremstår. Loyers fortælling kommer dermed til at stå i det "blur space," som de digitale tekstbehandlingsprogrammer skaber og ikke kan gengives på tryk. På forunderlig vis bliver forholdet mellem iscenesættelse og værk vendt på hovedet i The Lair, fordi historien om Orion17 lases som om den var produktet af Loyers oplevelse med arbejdet i det digitale scroll miljø.

Entropy8Zuper var vinderen af SFMOMAs Webby Prize 2000. Jeg har ikke plads til at komme nærmere ind på dette berømmede netkunstværk, men finder det værd at fremhæve nogle af de udtalelser kunstnerne bag værket er kommet med. Entropy8Zuper er skabt af Auriea Harvey og Michaël Samyn (31), og i et interview har Samyn udtalt:

I want to make environments that are immersive. My idol medium is the book. I want to make web sites that are as good as good novels...Art is not the goal, entertainment is. And art is a means to reach that goal: better entertainment. (32).
Samyn er ikke den eneste, der ynder ordet immersive. John Sanborn bruger det også, når talen falder på Dysson projektet (33). Koblingen mellem det immersive og romanen ligger lige for: den fordybelse og optagethed, som immersion kræver, er noget vi i århundreder har forbundet med romanen. Disse kunstnere fors $\emptyset$ ger dermed at transplantere det immersive til nettet, men at det sker på nettets præmisser, signaleres i deres tilføjelse af "environment," miljø. Og for at skabe sådanne miljøer på nettet, må radikale iscenesættelser tages i brug, hvis læser/publikum virkelig skal involveres.

\section{Fortsættelser følger...}

Denne gennemgang kan utvivlsomt beskyldes for at være kommet på alvorlige vildspor i sin jagt efter brudstykker af det litterære på nettet. Til det er der kun at bemærke, at det vildfarne og det at komme på afveje fra starten har været en grundlæggende del af attraktionen ved nettet, og at det er om at nyde denne mulighed, så længe den er der, og før meta-data standarder som Dublin Core lægger sig ned over nettet som en tung censurerende dyne. Det jeg håber at have vist er imidlertid, at de ting på nettet, der har markante og nyskabende relationer til aspekter, vi har for vane at kalde litterære, meget ofte også er dokumenter, der ikke lader sig omsætte til trykte. Holder man således fast i et kriterium, der siger, at værket på nettet er omskifteligt med bogen, som for eksempel glasbogen er, risikerer man at overse de steder, hvor tingene sker og kommer til at ske i fremtiden. Nettet er et hypermedie og dermed et medie, der placerer sig i grænselandet mellem alle kunstarterne. Derfor er deciderede og vellykkede netværker også nødvendigvis hybridformer. Der skal således arbejdes med en udvidet optik, der kan håndtere de permutationer, vi udsættes for på nettet, og netop iscenescettelse kan blive et nøgleord her. At det også involverer en anderledes inddragelse af læseren/publikum, og at så mange netskribenter stræber efter at skabe immersive værker, skyldes i $\mathrm{h} ø \mathrm{j}$ grad at romanen stadig fungerer som forbillede. Det immersive værk i hyperspace beskrives stadigvak bedst som "en god roman og mere til."

Jeg vil gerne takke Ide Hejlskov Larsen for hendes værdifulde hjælp og kommentarer i de sidste timer af arbejdet med denne artikel. 


\section{Noter}

1. Bram Stoker (1897): Dracula, p. 271 og frem. Jeg henviser til min slidte gamle udigitale udgave: Bantam Classic, 1981, men alle de nævnte klassikere kan altså downloades kvit og frit eventuelt gennem amazon.com.

2. Citeret fra The Complete Illustrated Works of Lewis Carroll, Chancellor Press, (1982) 1990, p. 738 .

3. "The End of Books," (1992) 1997, http://wings.buffalo.edu/cas/english/faculty/c onte/syllabi/370/EndofBooks.html (10-0201 ).

4. Coovers "short fictions" inkluderer bl.a. Pricksongs \& Descants (1969) og Spanking the Maid (1982). John Barth er især kendt for Lost in the Funhouse (1968), der har undertitlen Fiction for print, tape, live voice.

5. George P. Landow (1992): Hypertext: The Convergence of Contemporary Critical Theory and Technology, Baltimore: Johns Hopkins University Press. Se også antologien Hyper/Text/Theory (1994), George P. Landow (red.), Baltimore: Johns Hopkins University Press.

6. Det hypertekst værk som altid fremhæves er Afternoon: A Story af Michael Joyce. Kom oprindeligt i 1987 og senere genudgivet på CD-ROM i 1990 i softwaret Storyspace, som Joyce selv har været med til at udvikle. For beslægtede e-værker se http://directory.eliterature.org/ (10-02-01). Desuden har Charlotte Albrechtsen og Tine W. Jensen i forbindelse med deres speciale på Litteraturhistorie, Aarhus Universitet, udarbejdet 4 spændende guidede ture i ny e-litteratur, som findes på http://www.eforlag.dk/ (10-02-01).

7. http://www.whitney.org/collection/fs.html (10-02-01). Reelt består denne virtuelle udstilling af en link til Lehman College Art Gallery, hvor The Sentence startede i forbindelse med en udstilling og løber videre som en "on-going performance." I Whitneys intro oplyses det, at The Sentence består af mere end 200.000 bidrag.

8. http://ca80.lehman.cuny.edu/davis/ (10-0201 ). Dette er hjemmesiden for den vilde intro og brugsanvisning til The Sentence, og Douglas Davis er ansvarlig for sprog og typografi. På siden findes så det videre link til den egentlige sætning.

9. "Socially transformative" er det udtryk, David Ross brugte i forelæsningen: "Art and the Age of the Digital" afholdt på San Jose State University, d. 2-3-99. Transkription af forelæsningen og efterfølgende diskussion findes på http://switch.sjsu.edu/web/ross.html (10-02-01). David Ross beskriver også sammenhængen mellem videokunst og netkunst i artiklen: "Radical Software Redux" i Clicking In: Hot Links to a Digital Culture (1996), Lynn Hershman Leeson (red.), Seattle: Bay Pres.

10. Jævnfør herhjemme, hvor demokratisk lokalog kabel-tv nærmest er blevet synonymt med porno eller genudsendelser af amerikansk tv.

11. I "Mapping the Postmodern" i Andreas Hyussen (1986): After the Great Divide, London: MACMILLAN Press, 1988.

12. "Happenings: An Art of Radical Juxtaposition" i Susan Sontag (1966): Against Interpretation, New York: Dell Publishing Co., p. 270. Titlens "radical juxtaposition" henviser til Sontags kobling mellem happenings og en surrealistisk sensibilitet eller følsomhed, som hun betegner det. Sontag ser således det surrealistiske som en slags modus "which cuts across all the arts in the 20th century" (p. 271) og ikke begrænser sig eller skal begrænses til en bestemt kunstart eller bestemte kunstnere på et bestemt tidspunkt. Juxtaposition/collage er den teknik, den surrealistiske modus på en gang dyrker og anvender. Anskuet således kan en anden modus, der på samme måde "cuts across all the arts in the 20th century" være abstraktion/renselse. 
13. "Art and Objecthood" udkom oprindeligt $\mathrm{i}$ ARTFORUM, juni 1967. Jeg citerer fra Art in Theory: 1900-1990 (1992), Charles Harrison og Paul Wood (red.), Blackwell, 1996, p. 830. I relation til foregående note kan Fried ses som fortaler for en abstraktionsmodus. De kunstnere, Fried beklager sig over, er minimalister. ne Donald Judd og Robert Morris, men disses teatralske tilbøjeligheder kan også ses hos andre kunstnere. Som han skriver i note 4: "It is theatrcality, too, that links all these artists to other figures as disparate as Kaprow, Cornell, Rauchenberg, Oldenburg, Flavin, Smithson, Kienholz, Segal, Samaras, Christo, Kusama...the list could go on indefinitely." (p. 833)

14. Michael Krantz: "Is Denny Really Dead? An edgy E-mail prank (or is it art?) ruffles feathers while testing the limits of online storytelling," TIME, d. 4-8-97, vol.150 no. 5. Findes på http://www.time.com/time/magazine/1997/dom/970804/technology.is_deny_realy.html (10-02-01)

15. http://www.lafong.com/ (10-02-01). På denne hjemmeside beskrives LaFongs øvrige aktiviteter, og der er links til biografier og til en beskrivelse af Dysson projektet. Desværre er der på dette tidspunkt ikke længere adgang til Dysson hjemmesiden. Jeg kan kun tilslutte mig Krantz' beskrivelse af denne og så i $\emptyset$ vrigt spekulere på om Krantz undervejs fik det password, der krævedes for at komme længere ind i Dysson siden.

16. Ifølge Krantz. Jeg var desværre ikke en af de udvalgte 40 .

17. Donna Haraway (1989): Primate Visions, London/New York: Verso, 1992, p. 279.

18. For en dansk beskrivelse af dette museum og andre af Barnums aktiviteter se: Martin Zerlang (1989): Underholdningens historie, Gyldendal.

19. At Barnums museum også har forbløffende meget tilfælles med vore dages største raritetskabinetter, nemlig tv og nettet, kan jeg desværre ikke nå at uddybe her.
20. Neil Harris (1973): Humbug: The Art of P. T. Barnum, University of Chicago press, 1981, p. 57. I min Ph.d.-afhandling Envejsrude/Tovejsspejl, der er under udarbejdelse, argumenterer jeg for at læse denne humbug modus på lige fod med de i note 12 og 13 omtalte modi: collage/juxtaposition og abstraktion/renselse. I modsætning til disse har humbug den fordel, at det er et fænomen forankret i populærog mediekulturen og samtidig kan læses som en avantgarde strategi. På denne måde er en humbug modus et godt og, for mig at se, nødvendigt supplement $i$ en medieforskning, der søger radikale potentialer i samtidens mediebillede, men ofte havner i forklaringsproblemer, når såkaldte finkulturelle greb, der forbindes med collage/juxtaposition og abstraktion, lokaliseres i massemedierne.

21. Eksempler på berømte broadcasting humbugnumre er Orson Welles' radio-iscenesættelse af H. G. Wells: Klodernes kamp på CBS i 1938. The Blair Witch Project (1999) af Daniel Myrick og Eduardo Sánchez er også et eksempel. Som mediepakke bestod projektet oprindeligt at en tv-dokumentar, et net-site, biograffilmen og det løse, d.v.s. plakater og annoncer, der efterlyste de medvirkende. På hver deres måde kan filmen, tv-programmet og net-delen læses som en kommentar til og udstilling af hvilke æstetiske virkemidler, der skaber en aura af autenticitet indenfor de respektive medier og genrer.

22. Jeg mener altså, det vil være en fejltagelse at undervurdere det skrivearbejde, der kræves i disse sammenhænge. Udover at ordlyden i de involverede tekster skal være klokkeklar, skal teksten også være skærmklar m.h.t. valg af font o.s.v.. Allerede nu signalerer forskellige fonter autenticitet i bestemte sammenhænge. Går man således ind og ser på "virus hoaxes," falske virus advarsler, er den primitive font, der anvendes i mange af disse, klart et fors $\emptyset \mathrm{g}$ på at simulere en autenticitet, der knytter sig til E-mailens tidlige look og måske endog til skrift blot et skridt fra programmeringssprog. Eksempler på "virus hoaxes" findes på: http://hoaxbusters.ciac.org/ (10-02-01). "Virus hoaxes" er et meget 
udskældt fænomen, men også ganske underholdende. Måske disse falske virus advarsler i fremtiden vil blive læst som nettets "folkeviser."

23. The Blair Witch Project er selvfølgelig også et eksempel på en vellykket generator.

24. http://www.lafong.com/lafong/dysson.html (10-02-01).

25 http://www.emailshows.com (10-02-01).

26. http://www.sfmoma.org (10-02-01).

27. http://www.yhchang.com/ (10-02-01).

28. Det har desværre været umuligt for mig at identificere musikken. En af de eksperter, jeg konsulterede, overvejede om det kunne være Michel Camilo eller George Shearing på speed

29. Jævnfør det tidligere Sontag citat.

30. Findes altså på SFMOMAs site under e(space.

31. Søren Mørk Petersen har i sin studieopgave Love.art, Danmarks Biblioteksskole, København, d. 4-1-01, meget udførligt beskrevet og analyseret dette værk og hvordan det fungerer som en kærlighedshistorie med Samyn og Harvey som hovedpersoner.

32. Interviewet er oprindeligt fra Rhizome Digest, d. 18. april, 2000, men findes også på http://www.afsnitp.dk/onoff/home.html (1002-01). ON OFF er i det hele taget værd at konsultere. Siden det startede i december 2000 , har blandt andet deres fortegnelse over relevante links været den bedste på sit område $i$ landet.

33. I Krantz op.cit..

\section{Litteratur}

Lewis Carroll (1876): The Hunting of the Snark i The Complete Illustrated Works of Lewis Carroll, Chancellor Press, (1982) 1990.

Robert Coover (1992): "The End of Books," 1997, findes på

http://wings.buffalo.edu/cas/english/faculty/conte/syllabi/370/EndofBooks.html (10-02-01).

Michael Fried (1967): "Art and Objecthood"i Art in Theory: 1900-1990 (1992), Charles Harrison og Paul Wood (red.), Blackwell, 1996.

Donna Haraway (1989): Primate Visions, London/New York: Verso, 1992.

Neil Harris (1973): Humbug: The Art of P. T. Barnum, University of Chicago Press, 1981.

Andreas Huyssen: "Mapping the Postmodern" i Andreas Huyssen (1986): After the Great Divide, London: MACMILLAN Press, 1988.

Michael Joyce (1987/1990): Afternoon: A Story.

Michael Krantz: "Is Denny Really Dead? An edgy E-mail prank (or is it art?) ruffles feathers while testing the limits of online storytelling," TIME, d. 4-8-97, vol. 150 no. 5.

George P. Landow (red.) (1994):

Hyper/Text/Theory, Baltimore: Johns Hopkins University Press.

George P. Landow (1992): Hypertext: The Convergence of Contemporary Critical Theory and Technology, Baltimore: Johns Hopkins University Press.

David Ross (1999): "Art and the Age of the Digital" findes på http://switch.sjsu.edu/web/ross.html (10-02-01).

David Ross (1996): "Radical Software Redux" i Clicking In: Hot Links to a Digital Culture (1996), Lynn Hershman Leeson (red.), Seattle: Bay Press.

Susan Sontag (1962): "Happenings: An Art of Radical Juxtaposition" i Susan Sontag (1966): 
Against Interpretation, New York: Dell Publishing Co.

Bram Stoker (1897): Dracula, Bantam Classic, 1981.

Martin Zerlang (1989): Underholdningens historie, Gyldendal.

\section{Netsteder:}

http://ca80.lehman.cuny.edu/davis/ (10-02-01)

http://directory.eliterature.org/ (10-02-01)

http://hoaxbusters.ciac.org/ (10-02-01) http://www.afsnitp.dk/onoff/home.html (10-02-01)

http://www.eforlag.dk/ (10-02-01)

http://www.emailshows.com (10-02-01)

http://www.lafong.com/ (10-02-01)

http://www.sfmoma.org (10-02-01)

http://www.whitney.org/collection/fs.html (10-0201)

http://www.yhchang.com/ (10-02-01) 